\title{
A Pebble in the Shoe: Assessing the Uses of Do No Harm in International Assistance
}

\author{
By Adrian Di Giovanni*
}

\begin{abstract}
This paper assesses from an international law perspective the increasing use of "Do No Harm" as a principle to guide a broad array of international activities, such as state-building, human rights and climate change. Originally a medical principle derived from the Hippocratic Oath, Do No Harm's increased use has coincided with greater attention to the responsibility of international actors who, when setting out to do 'good, ' have tried to ensure that activities do not cause harm or make things worse off. Do No Harm is nowhere found in binding sources, treaties or otherwise, but is invoked in connection with a range of international legal norms in a varied and inconsistent manner. The basic assumption that this paper seeks to test then is that Do No Harm is not living up to its self-stated role, serving rather to defer a series of policy or political choices concerning the nature or apportionment of various actors' responsibility. To that end, the paper describes some general features of Do No Harm's uses, followed by a more in-depth discussion of uses in humanitarian assistance, international human rights and international environmental law. That discussion reveals that Do No Harm does flag gaps in the regulation of international conduct, but does not resolve inherent trade-offs that arise when seeking to avoid harm. Those trade-offs are especially pronounced where Do No Harm's different uses overlap and risk engendering either a false sense of coherence between competing priorities, or an overly technocratic approach to risk mitigation and performing prior assessments of possible impacts of activities. The larger analysis is ultimately a call for greater conceptual clarity, when faced with the convenience offered by Do No Harm's incontrovertible veneer.
\end{abstract}

$* * *$

\section{Introduction}

"Do No Harm" increasingly appears in a broad array of international contexts, as a principle of conduct for actors engaged in different forms of international activity. Originally a medical

* BA (McGill), LL.B. (Toronto), LL.M. (New York), Senior Program Officer, Law \& Development, International Development Research Centre, Canada, adigiovanni@idrc.ca. The author wishes to thank the editorial staff, participants in 2012 ASIL Mid-Year Meeting, the Department of Justice Canada's international law working group, Philipp Dann and Jane Arbour for invaluable feedback on the paper, as well as to Alanna Karpa for helpful background research. Any outstanding errors are entirely my own. 
principle (primum non nocere) derived from the Hippocratic Oath, references to it now appear in connection to peacekeeping, state-building, human rights and business, human rights approaches to development and environmental impact assessments. More broadly, Do No Harm's increased use has coincided with greater attention to international responsibility of actors, whether states extraterritorially, international organizations or private actors. On the surface, this transplantation is easily grasped. Given the ever-changing set of contexts faced by international actors when setting out to do 'good,' at a minimum, they should ensure that their activities do not cause harm or make things worse off than if they had not acted at all. Do No Harm thus appears to offer a useful principle for developing minimum rules of professionalism for international conduct. It flags areas where regulation of conduct is currently insufficient and in need of further clarity. This paper sets out to assess those uses from an international law perspective.

A cursory review reveals that Do No Harm is nowhere found in binding sources, treaties or otherwise. Rather, it is invoked in connection with an array international legal norms in a varied and inconsistent manner. Do No Harm language thus tends to take on a legal appearance in a number of ways, variously, as a short-hand for existing hard law norms, in support of efforts to progressively extend their application or as part of attempts to develop new norms of a voluntary or soft nature. To what extent, then, does Do No Harm provide a useful principle for regulating international activities and promoting greater accountability? Underlying this question is a nagging worry that Do No Harm might not be living up to its self-stated role, that is, serving to defer a series of policy or political choices concerning the nature or apportionment of various actors' responsibility. This is the basic assumption that this paper seeks to test, namely, Do No Harm's increased popularity and use is due to the intuitive, even seductive ease, with which it captures existing gaps in the regulation of conduct and the need for clearer rules. At the same time, however, because 'Do No Harm' is so simple and selfevident on the surface, it may serve too quickly to provide a certain authority, ethical or otherwise, for various types of conduct. Its ostensibly indisputable status (after all who would want to be seen to be doing harm?) may thus serve to stifle further discussion about key underlying issues, such as what 'Doing No Harm' more concretely entails in a given context. Stated simply, is it just an exercise in rhetorical window-dressing or is it a workable or meaningful principle to regulate conduct?

In order to answer those questions, Section A of this paper introduces, as a conceptual backdrop for assessing Do No Harm's various uses, the increased attention paid to issues of global governance and the regulation of international activities. Some general features of Do No Harm's uses are also described. A more in-depth discussion is then provided about Do No Harm's uses in the areas of humanitarian assistance (Section B) and human rights (Section C). Those discussions reveal that Do No Harm does indeed serve to flag existing gaps in the regulation of international conduct, but does not resolve tensions over what principles are most appropriate to a particular set of actors or activities. In Section D, notions of doing no harm under international environmental law are briefly examined, in order to bring out additional commonalities and risks in using Do No Harm across the three areas of environmental 
law, humanitarian assistance and human rights. All three areas coalesce around a respective principle to perform prior assessments of the impact of planned interventions. This principle, however, could suggest an overly technocratic approach to addressing possible harms arising from international activities.

Section E finally examines converging spaces of operation, in which Do No Harm's different uses risk colliding and, in turn, engendering a false or premature sense of coherence between areas such as humanitarian assistance, human rights and the environment. Do No Harm's uses in those contexts is ultimately limited because the question of what 'harm' is that is, which regime's diverging definition of harm should apply - is left unresolved. In this sense, Do No Harm's uses across regimes parallels, but cannot resolve, and may potentially mask, larger debates in international law and policy about how to balance competing priorities or resolve clashes between applicable norms. In the final analysis, drawing conclusions about Do No Harm's various uses is challenging because so much is left silent when it is invoked. The larger analysis provided here, in this sense, is ultimately a call for greater conceptual clarity, and to resist the temptation of convenience offered by Do No Harm's incontrovertible veneer.

\section{A. Do No Harm within larger discussions of the Regulation of International Activities}

\section{Conceptual Backdrop}

The Do No Harm principle has its origins in the Hippocratic Oath, which has a rich history dating back to Ancient Greece over 2400 years ago. ${ }^{1}$ Although it is often portrayed as the core ethical principle of the medical profession, the Hippocratic Oath appears to occupy a somewhat ambiguous role. It is described, alternately, as "an honored relic" recited once a year at medical school graduation ceremonies, a "respected template upon which new statements of medical professionalism are devised" or as a blunt instrument used to assert moral authority and trust-worthiness of the medical profession - as a trump - over other fields in controversial policy debates. ${ }^{2}$ Why then the increased emphasis on and uses of Do No Harm in international assistance circles, given its far from clear status in its original professional setting?

The main concern, in setting out to answer this question, was to determine whether Do No Harm provides a useful principle for developing new international law norms and rules and extending existing ones. A particular focus, in this respect, was placed on assessing the potential of Do No Harm to promote accountability or, conversely, what detracting effects its current uses might have. This concern arises in part because historically Do No Harm's increased use coincides with efforts to strengthen the regulation of international activities and

1 Steven H. Miles, The Hippocratic Oath and the Ethics of Medicine, New York 2004. Interestingly, "Do No Harm" does not actually appear in the Hippocratic Oath even though the two are often seen as synonymous (for more detail see pp. 44-5 and also C.M. Smith, Origin and Uses of Primum Non Nocere - Above All, Do no Harm!, The Journal of Clinical Pharmacology 45 (2005), p. 331.

2 Ibid. 2, 4. 
actors. In a number of further cases, Do No Harm is used in direct connection with existing and emerging international legal norms. Do No Harm can thus be situated within larger debates about global governance and the regulation of international activities, and as part of the vocabulary of clarifying basic principles to guide international conduct, legal or otherwise. The conceptual backdrop for assessing Do No Harm's increased use, in this respect, is the increased attention paid in past decades to the regulation and accountability for international activities under international law. The growing concern for accountability can be explained in large part by the increase "in the reach and forms of transgovernmental regulation and administration designed to address the consequences of globalized interdependence." 3 Indeed, with the changing nature of international problems, responses and actors has come an increased focus on the need for new or adapted legal principles and forms of regulation, over and above those classically governing the relations between sovereign states. ${ }^{4}$

This focus can be seen in relation to development, humanitarian assistance in conflict settings, disaster relief, and peacekeeping, to name a few. ${ }^{5}$ In the case of development, examples include an array of efforts, both hard and soft law in nature, such as domestic legislation and use of private law to increase accountability of states for development assistance, ${ }^{6}$ attempts to apply human rights more explicitly to development, ${ }^{7}$ and the establishment of inspection panels within multilateral development banks to review negative impacts of projects. ${ }^{8}$ Similarly, there have been efforts to increase regulation of the conduct of non-state actors, especially transnational corporations, whether through attempts to extend the scope of existing human rights obligations of states extraterritorially to the acts of private entities in

3 Benedict Kingsbury, Nico Kirsch, and Richard B. Stewart, The Emergence of Global Administrative Law, Law \& Contemp. Probs. 68 (2005), p. 16.

4 The literature on this topic is vast, but to name a few, see generally Abram Chayes and Antonia Handler Chayes, The New Sovereignty: Compliance with International Regulatory Agreements, Cambridge 1998, p. 272; Christoph Schreuer, The Waning of the Sovereign State: Towards a New Paradigm for International Law, EJIL 4 (1993); Kofi Annan, Two Concepts of Sovereignty, The Economist (18 September 1999), p. 38. .

5 Kingsbury, Kirsch, and Stewart, note 3, p. 16 provides a longer list.

6 Respectively, Official Development Assistance Accountability Act, R.S.C. 2008, c. 17 (Canada); International Development (Reporting and Transparency) Act, 2006 c. 31 (United Kingdom); and Amir Attaran, Will Negligence Law Poison the Well of Foreign Aid? A Case Comment on: Binod Sutradhar v. Natural Environment Research Council, Global Jurist Advances 6 (2006).

7 Peter Uvin, From the Right to Development to the Rights-Based Approach: How 'Human Rights' Entered Development, Development in Practice 17 (2007); The Human Rights Based Approach to Development Cooperation - Towards a Common Understanding Among UN Agencies ("Stamford Declaration"), Second Inter-agency Workshop, Stamford 2003.

8 Daniel Bradlow, Private Complainants and International Organizations: A Comparative Study of the Independent Inspection Mechanisms in International Financial Institutions, Geo. J. Int'1 L. 36 (2005). 
foreign states, ${ }^{9}$ to apply human rights directly to businesses,${ }^{10}$ as well as an array of voluntary guidelines and codes of conduct for banks, resource extraction operations, and private military companies. ${ }^{11}$ Finally, greater attention has been paid to accountability in relation to international organizations and their operations, ${ }^{12}$ including the obligations of states as members of organizations intervening in military or peacekeeping operations, ${ }^{13}$ as well as general principles related to emergency or disaster situations, ${ }^{14}$ and a focus on post-conflict administration of territories. ${ }^{15}$

In the most general terms, these various normative projects tie together because, in one way or another, they seek to ensure the regulation of international activities according to clear principles, especially as relates to the accountability of international actors to the parties directly affected by the activities in question. Further, these efforts to clarify or develop new principles in relation to various subjects and spheres of activity could be seen as part of broader efforts to 'humanize' international law, that is, a more systematic shift in emphasis, onto the individual and away from the sovereign state as the exclusive subject or concern of international law. ${ }^{16}$ The distinctive feature of Do No Harm, when viewed against this backdrop, is

9 Sigrun Skogly, Beyond National Borders: States' Human Rights Obligations in International Cooperation, Antwerp/Oxford 2006; Theodor Meron, Extraterritoriality of Human Rights Treaties, AJIL 89 (1995); Jacco Bomhoff, The Reach of Rights: "The Foreign" and "The Private" in Conflict-ofLaws, State-Action, and Fundamental-Rights Cases with Foreign Elements, Law \& Contemp. Probs. 71 (2008).

10 See e.g., John H. Knox, Horizontal Human Rights Law, AJIL 102 (2008), p. 1; John Ruggie, Guiding Principles on Business and Human Rights: Implementing the United Nations "Protect, Respect and Remedy" Framework, UN Doc. A/HRC/17/31 (2011).

11 Respectively, The Equator Principles (2006), www.equator-principles.com (last accessed on 17 March 2014); The Extractive Industries Transparency Initiative, http://eiti.org (last accessed on 17 March 2014); ICRC, The Montreux Document on pertinent international legal obligations and good practices for States related to operations of private military and security companies during armed conflict (2009), www.icrc.org (last accessed on 17 March 2014).

12 See e.g. International Law Commission, Report of the International Law Commission, 59th session (7 May-5 June and 9 July-10 August 2007), UN Doc. A/62/10 (2007). See also Joined Cases C-402/05 P \& C-415/05 P, Kadi \& Al Barakaat v. Council of the European Union and EC Commission, 3 C.M.L.R. 41 (2008) for judicial consideration of the UN Security Council's obligations.

13 See e.g. App. No. 52207/99 Banković and others v. Belgium and others, Grand Chamber decision of 12 December 2001.

14 See e.g. International Law Commission, Protection of Persons in the Event of Disasters: Texts and Titles of Draft Articles 10 and 11 Provisionally Adopted by the Drafting Committee on 19 July 2011, U.N. Doc. A/CN.4/L.794 (2011).

15 Simon Chesterman, International Territorial Administration and the Limits of Law, Leiden J. of Int'1 Law 23 (2010).

16 See e.g. Antonio Cassese, International Law, $2^{\text {nd }}$ ed., Oxford (2005), p. 45. Hélène Ruiz Fabri, Human Rights and State Sovereignty: Have the Boundaries been Significantly Redrawn? in Philip Alston and Euan Macdonald (eds.), Human Rights, Intervention, and the Use of Force, Oxford 2008, p. 33; David Kennedy, The Disciplines of International Law and Policy," 12 Leiden J. Int'1 9 (1999). 
precisely that it takes, as its starting point, the condition of those parties or concerns most likely to be affected by the conduct in question.

\section{General Features}

The most basic questions examined, in seeking to understand better Do No Harm's contributions to increased accountability of international actors, were "Do No Harm to what or whom?" and according to whom? ${ }^{17}$ From there, Do No Harm's uses were examined from a number of vantage points. ${ }^{18}$ As a first step, the uses were examined chronologically, so as to trace the trajectory of Do No Harm's uses, in particular, to what extent the principle has gained in popularity and spread across different spheres of activity - especially between legal and non-legal spheres. Building on the historical perspective, uses were also examined in terms of the normative weight ascribed to Do No Harm, for instance, whether it is treated as a legal norm (hard law or soft law), an ethical principle, a policy or political goal, a technical standard of best practice or, at the extreme, vacuous of meaning and intention. In this connection, a focus was placed on what consequences and responsibility were prescribed where harm occurs (e.g. "hard responsibility, hard sanctions") particularly in respect to procedural and substantive notions of remedy, which stood in as main proxies for legal accountability for harm to individuals. ${ }^{19}$ In analysing the normative weight ascribed to the principle, attention was also paid to the generality or specificity of the meaning ascribed to Do No Harm; for instance, whether the prescription is defined in explicit detail, implicitly but denoting recognized practice (i.e.

17 Siobhan McInerney-Lankford, Mac Darrow, and Lavanya Rajaman, Human Rights and Climate Change: A Review of the International Legal Dimensions, Washington D.C. 2011, p. 46.

18 Note, locating references to Do No Harm, in a systematic manner, proved to be its own challenge, as there has been little academic treatment of the principle, especially under international law. Initially, the desk review of uses involved broad web-based searches and in academic and legal databases, as well as pre-identified sources known to be valuable. The websites of a number of bilateral and multi-lateral donor agencies as well as large civil society organizations were also targeted. Despite efforts to be as exhaustive as possible, there were some inherent limitations in this initial mapping exercise. For instance, searches of grey literature were for the most part limited to internet-based content using English search terms (viz. "Do No Harm," "No Harm"). Indeed, a valuable follow-up line of enquiry would be to determine whether Do No Harm concepts are used in other languages, and, if so, to what extent any conceptual differences arise in its application. That said, given the focus on major actors, the mapping exercise can, nonetheless, be said to capture indicative trends of Do No Harm's use globally. Note, some areas were deliberately excluded because to avoid making the discussion overly broad, for instance, references in medical and research ethics contexts.

19 The language of "hard responsibility" and "hard sanctions" is borrowed from Jan Klabbers, The Redundancy of Soft Law, Nordic Journal of International Law 65 (1996), p. 169 who uses those terms to contrast hard law to non-law. A deeper theoretical discussion of remedies and legal accountability under international law is beyond the scope of this paper. For simplicity, the notions of relief and remedies follow a basic human rights' notion of accountability to individuals and "embrace the substance of relief as well as the procedures through which relief may be obtained. Remedies may include an award of damages, declaratory relief, injunctions or orders, and attorneys fees and costs." Dinah Shelton (ed.), Remedies in International Human Rights Law, Oxford, 2010, p. 8. 
as a 'shorthand'), or tacitly without much more explanation. In the same vein, an effort was made to distinguish between Do No Harm's uses as a 'rule' and a 'principle,' namely, "a concrete prescription" and a more abstract rule or policy. ${ }^{20}$ The type of conduct prescribed was also assessed, specifically, whether Do No Harm is defined in procedural or ex ante terms (before or when acting, ensure $\mathrm{x}, \mathrm{y}, \mathrm{z}$ steps are taken), which could be said to encompass a risk mitigation approach, or more in terms of substantive outcomes (before or when acting, ensure that $\mathrm{x}, \mathrm{y}, \mathrm{z}$ harms do not occur).

The general conclusion that emerges from reviewing the various uses of Do No Harm is that it has been invoked with increasing frequency, following its introduction in international circles in connection to humanitarian assistance, during the mid-1990 s. Only in three main areas, however, Do No Harm's content been developed to any degree of detail: humanitarian assistance, human rights and international environmental law. As will be shown, the meaning ascribed to Do No Harm in each respective context is different, in terms of the types of responsibility and normative weights attached to it. A common thread that ties the uses of Do No Harm's uses together is that it nowhere appears in a binding international law document, such as a treaty, even in those contexts where it is ascribed more detailed meaning. Rather, at the most, Do No Harm appears in various ways in connection with existing obligations or attempts to develop new ones. In those instances, as a legal norm, Do No Harm falls somewhere in the category of soft law, that is, in the "large grey zone in between, occupied by those documents and instruments which are not clearly law, but cannot be said to be legally insignificant either."21 The various 'soft law' uses of Do No Harm are examined more systematically below. ${ }^{22}$

Do No Harm language also appears without the same level of detail, in connection with numerous forms of international activity. Examples are found in a variety of academic articles, and best practice, policy and program documents dealing with micro-credit programs, ${ }^{23}$ postconflict employment creation and income generation programs; ${ }^{24}$ trade sanctions and nego-

20 Jochen von Bernstorff and Philipp Dann, Reforming the World Bank's Safeguards, A comparative Legal Analysis, Bonn/Berlin 2013, p. 9.

21 Klabbers, note 19, p. 167.

22 Note, a deeper presentation of the theoretical validity of soft law as a category of international law is beyond the scope of this paper. Soft law language will be used rather to explain different characteristics of Do No Harm's uses. For additional background on the theoretical debates, see e.g. Klabbers, note 19; Dinah Shelton (ed.), Commitment and Compliance: The Role of Non-binding Norms in the International Legal System, Oxford 2003; Matthias Goldmann, We Need to Cut Off the Head of the King: Past, Present, and Future Approaches to International Soft Law, Leiden J. of Int'l Law 25 (2012), p. 335; Eibe Reidel, Standards and Sources. Farewell to the Exclusivity of the Sources Triad in International Law?, EJIL 2 (1991), p. 57.

23 David Rodman, What (Not) to Expect of Microfinance in Haiti, Testimony for the House Financial Services Subcommittee on International Monetary Policy and Trade (28 April 2010), http://www.c gdev.org (last accessed on 17 March 2014).

24 United Nations, United Nations Policy for Post-Conflict Employment Creation, Income Generation and Reintegration, Geneva 2009. 
tiations $;{ }^{25}$ democracy promotion; ${ }^{26}$ anti-corruption strategies $;{ }^{27}$ fiscal policy reforms,${ }^{28}$ institutional reforms more generally; ${ }^{29}$ HIV/AIDS programming; ${ }^{30}$ and U.N. peacekeeping. ${ }^{31}$ Do No Harm in those cases tends either to map the humanitarian assistance uses discussed below or, for the most part, is cited 'in passing' without much elaboration. There is thus a tendency for Do No Harm to appear at the beginning of discussions, to note that activities should at least 'no do harm,' before proceeding with a deeper discussion of the best or proper way to carry out a specific set of interventions or activities. Given the lack of further guidance, it is difficult to conclude much about the 'in passing' uses, other than that, in those instances, Do No Harm is nowhere treated as a legal norm, and invariably appears in connection with more elaborate discussions about 'getting it right' or 'doing good'. That said, in failing to spell out more clearly what Do No Harm means, across a variety of contexts, the 'in passing' uses generally fall silent on the crucial issue of what the consequences should be where harm occurs. To be fair, the in-passing uses are not alone in this respect. To set the stage for the discussion that follows, even where Do No Harm is defined in more detail, a clear indication of the consequences for causing harm - who should be accountable to whom and how - is largely absent. The principle is there to avoid harm, but the consequences for failing to followthrough on it are left largely unstated.

25 Michael Ewing-Chow, First Do No Harm: Myanmar Trade Sanctions and Human Rights, Nw. Univ. J. Int'l Hum. Rts. 5 (2007), pp. 154-8; Çaglar Özden and Eric Reinhardt, First Do No Harm: The Effect of Unilateral Trade Preferences on Developing Country Exports, www.cepr.org (last accessed on 17 March 2014); Christopher Stevens and Lauren Phillips, Creating Country Trade Negotiating Strategies: A Handbook (2007), www.odi.org.uk/resources/docs/4124.pdf (last accessed on 17 March 2014).

26 United Nations, Guidance Note of the Secretary-General on Democracy (2009).

27 Michael Johnston, First Do No Harm - Then, Build Trust: Anti-Corruption Strategies in Fragile Situations, World Development Report 2011 - Background Paper, Washington, D.C. 2011); USAID, Assessment of Corruption in Afghanistan: January 15, 2009 - March 1, 2009, Washington, D.C., 2009.

28 Murilo Portugal, Opening Remarks by Murilo Portugal, Deputy Managing Director, IMF, Delivered at a Seminar on Financial Sector Taxation (16 September 2010), http://www.imf.org (last accessed on 17 March 2014); Carlos Garcia, Jorge E. Restrepo, and Evan Tanner, Fiscal Rules in a Volatile World: A Welfare-Based Approach, IMF Working Paper (2011).

29 See e.g. Nancy Birdsall, "Do No Harm: Aid, Weak Institutions and the Missing Middle in Africa," Development Policy Review Vol. 25(5) 575 (September 2007).

30 Nandini Oomman, David Wendt, and Christina Droggitis, Zeroing In: AIDS Donors and Africa's Health Workforce

(2010), http://www.cgdev.org (last accessed 17 March 2014), pp. 1, 5; UNDP, Marginalised Minorities in Development Programming: A UNDP Resource Guide and Toolkit, New York 2010.

31 UN DPKO and DFS, Civil Affairs Handbook, New York 2012. 


\section{B. Humanitarian Assistance, Peace-Building and State-Building}

References to Do No Harm in the humanitarian assistance context date back to the early $1990 \mathrm{~s}$, for instance, in connection with the United States' intervention in Somalia. ${ }^{32}$ The main genesis of the term is often attributed to the work of Mary Anderson, ${ }^{33}$ though Do No Harm language and its deliberate borrowing from the Hippocratic Oath appears to have been percolating across US assistance circles at the time, eventually to crystallize as a new "paradigm" or "development in the thinking behind relief policy." 34 The basic aim underlying Do No Harm's use at the time was to underscore the need to conduct better analysis of the actors and dynamics of conflicts, in order to avoid the possible negative impacts of humanitarian aid, for instance, exacerbating divisions between groups or fuelling war economies. Do No Harm's use in this sense emerged from a deeper recognition that, while intended to alleviate the suffering of conflict, humanitarian assistance can actually feed into and exacerbate conflicts. ${ }^{35}$

This shift to a logic of doing no harm can be situated within larger re-examinations of traditional humanitarian principles such as neutrality, impartiality, the humanitarian imperative and non-intervention when administering aid, which had long guided organizations such as the International Committee of the Red Cross (ICRC). To condition or tailor the provision of aid according to the dynamics of the conflict, in short, might mean not providing aid to specific groups in need, out of risk of exacerbating the fighting or its negative impacts on other groups. This might effectively mean taking sides, thereby compromising neutrality or the humanitarian imperative, by aligning provision of aid more with groups on one side of the conflict than the other. At the time, Thomas Weiss characterised Do No Harm as a minimalist approach, at the centre of a spectrum of possible degrees of political involvement in conflicts by humanitarian actors, ranging from completely eschewing confrontation or political involvement (the traditional ICRC position), to complete identification and even solidarity with certain groups in a conflict (sometimes attributed to groups like Médecins sans Frontières). ${ }^{36}$ The debates over the continued validity of traditional humanitarian principles, without going into detail, help to demonstrate some of Do No Harm's features. When first introduced in the humanitarian aid context, Do No Harm helped to crystallise various tensions and

32 Richard H. Curtiss, In Somalia, the Goal Must Be "Do No Harm, The Washington Report on Middle East Affairs 4 (1993), p. 38.

33 Mary B. Anderson, Do No Harm: How Aid Can Support Peace - Or War, Boulder, CO, 1999. See also Fiona Terry, Condemned to Repeat? The Paradox of Humanitarian Action, Ithaca, NY, 2002, pp. 15-6, fn 36 for additional references. The Anderson work is most frequently cited as a supporting source, especially with 'in passing' uses, but without much more discussion of the book's content.

34 Barry Munslow, Christopher Brown, Complex emergencies: the institutional impasse, Third World Quarterly 20,1999, p. 210. Also cited in Terry, note 33, p. 16, fn. 37.

35 Terry, note 33, p. 1.

36 Thomas G. Weiss, Principles, Politics, and Humanitarian Action, Ethics \& International Affairs 13 (1999), p. 4. See also Terry, note 33, p. 26; Sorcha O'Callaghan and Sara Pantuliano, Protective action Incorporating civilian protection into humanitarian response, www.odi.org.uk (last accessed on 17 March 2014), pp. 4-5. 
trade-offs at the heart of the humanitarian venture, concerning inadvertent and even inevitable harms arising from assistance. In this way, Do No Harm helped focus attention on perceived shortcomings of classical humanitarian principles. ${ }^{37}$ This is the 'sign-post' role of Do No Harm. Thus, even as a non-legal norm, Do No Harm in this context appears to play the role commonly attributed to soft law norms, of helping fill gaps where existing principles might be thin and concerted action is needed. ${ }^{38}$

In the years since its emergence, Do No Harm has become an established principle of peace-building. It has been entrenched in the OECD's Principles for Good International Engagement in Fragile States and Situations (Principle 2), ${ }^{39}$ the policies and practices of major bilateral donors such as the United Kingdom and the United States, ${ }^{40}$ and has more recently also appeared in relation to state-building. ${ }^{41}$ This points to widespread consensus about Do Harm's importance, especially on the need to perform conflict analysis. Framed in that way, Do No Harm can best be described as a procedural and risk mitigation principle, which is intended to track the cycle of an intervention. ${ }^{42}$ Except for a notable exception, however, there is scant evidence within humanitarian assistance that Do No Harm is asserted as a legal norm, soft or hard, or that there should be legal consequences for failure to respect the principle. ${ }^{43}$

37 The heuristic value of Do No Harm has been confirmed for instance by $O E C D$, Monitoring the Principles for Good International Engagement in Fragile States and Situations - Fragile States Principles Monitoring Survey: Global Report, 2010, www.oecd.org (last accessed on 17 March 2014), p. 20. See also, O'Callaghan and Pantuliano, note 36, p. 5.

38 Christine Chinkin, Normative Development in the International Legal System, in: Shelton, note 22, p. 36; Dinah Shelton, Introduction: Law, Non-Law and the Problem of 'Soft Law,' in: ibid., p. 14; and Reidel, note 22, pp. 69-70.

39 OECD, Development Assistance Committee, Principles for Good International Engagement in Fragile States and Situations (2007), www.oecd.org (last accessed on 17 March 2014). Principle 2 also extends to more recent priority areas, such as taking into account the impacts of corruption and human rights abuses on local conditions, as well as the need to avoid corruption in administering aid and judge the impacts of suspending it.

40 Department for International Development (DfID UK), Briefing Paper B: Do No Harm - Working Effectively in Conflict-affected and Fragile Situations (March 2010), www.gsdrc.org (last accessed on 17 March 2014).

41 OECD, Do No Harm, International Support for Statebuilding (2010), www.oecd.org (last accessed on 17 March 2014), p. 28.

42 See e.g. O'Callaghan and Pantuliano, note 36, p. 30.

43 A notable exception is The Sphere Project, Handbook on Humanitarian Charter and Minimum Standards in Humanitarian Response $3^{\text {rd }}$ ed., Rugby, UK 2011. The Handbook characterises the Minimum Standards as being firmly grounded in both legal and moral principles, and also recognizes an increased focus on accountability of humanitarian assistance actors, for instance, under the InterAgency Standing Committee (IASC). Use of Do No Harm in the Standards, though, does not appear in connection with accountability but could in this case be said to be part of a larger push for increased accountability. See also Yale Law School, Transnational Development Clinic, Peacekeeping without Accountability: The United Nations' Responsibility for The Haitian Cholera Epidemic (2013), www.law.yale.edu (last accessed on 17 March 2014) which asserts that Do No Harm is a legal norm that has risen to the (hard) status of customary international law. Strikingly, this report makes a rarely 
If anything, some of the main practical guidance associated with Do No Harm is deliberately labelled as non-prescriptive. ${ }^{44}$ The term 'responsibility' does appear in a number of places (e.g. in connection to the OECD Principle 2) but with little explanation of what status such a responsibility occupies or, crucially, what the consequences should be where harm occurs. ${ }^{45}$ Thus, while Do No Harm appears to carry strong normative weight, as a principle to guide policy and practice, it remains at an ethical level. At the same time, there is evidence to suggest that the principle has failed to translate meaningfully into practice, despite the strong importance attached to it. ${ }^{46}$ Consider, for instance, an assessment of humanitarian assistance in Sudan and Sri Lanka, which concluded that donor "efforts to 'do no harm' remain essentially ad hoc with, as yet, no coherent set of principles, standards or guidelines to inform policymaking and decision-making in practice." 47 Similarly, an OECD evaluation of the Do No Harm Principle 2 concluded that "[t]here was little evidence that international actors have attempted to assess these risks on a systematic basis, or to consider the need for mitigating measures. The trade-offs between the different objectives of international engagement have not been confronted head-on or subjected to explicit debate." 48

Those conclusions suggest, broadly, that there has been limited progress in international policy circles in resolving the trade-offs and dilemmas that spurred the original entrance of Do No Harm into the international lexicon. In this sense, Do No Harm arguably has not stretched beyond the 'sign-post' role, to help address more concretely the need for clearer rules that it originally drew attention to. Finally, as noted, little guidance appears to have been developed concerning what the consequences should be where harms do arise, let alone any indication of if and how actors have taken responsibility in actual situations of harm. The concern about responsibility is particularly acute when measured against this discussion's conceptual backdrop. The lack of documented cases of actors assuming responsibility for

found assertion at p. 45 that Do No Harm in the humanitarian assistance field includes "a commitment to establish mechanisms of accountability for [harmed] populations."

44 See e.g. Collaborative for Development Action, Inc. and CDA Collaborative Learning Projects, The Do No Harm Handbook (The Framework for Analyzing the Impact of Assistance on Conflict) (2004), www.cdacollaborative.org (last accessed on 17 March 2014), p. 3 which says: "The Framework is NOT prescriptive..." [emphasis in original].

45 In this connection, see generally Terry, note 33, Chapter 2 on links between responsibilities associated with humanitarian action and the larger framework of international humanitarian law.

46 Notably, guidance for factors to analyse when conducting the conflict analysis, central to the principle's application, appears in relation to all stages of intervention (e.g. from inception to implementation to final evaluation) Among others, see e.g. USAID, USAID Assistance to Internally Displaced Persons Policy (October 2004), http://transition.usaid.gov (last accessed 17 March 2014), p. 6.

47 Sarah Collinson, Margie Buchanan-Smith and Samir Elhawary, Good Humanitarian Donorship Principles in Practice: Assessing humanitarian assistance to internally displaced persons in Sudan and Sri Lanka, Overseas Development Institute HPG Commissioned Report (2009), www.odi.org. uk (last accessed 17 March 2014), p. 4.

48 OECD, note $37 ; D f I D U K$, note 40 , discusses e.g. immediate service delivery versus capacity development; immediate security versus long-term stability; and poverty reduction versus addressing inequality as examples of competing objectives; see also $O E C D$, note 41, p. 28. 
harms, under the rubric of Do No Harm casts further doubts on its value as a principle to regulate international activities. ${ }^{49}$ For now, an open question to consider in respect to humanitarian assistance is why the apparent consensus around Do No Harm, at an ethical, policy and technical level, has not translated more meaningfully into practice (or why there is no stronger evidence to that effect). To echo an early observation by Fiona Terry, query whether Do No Harm may have provided a pretext for inaction, namely, that "[e]mphazing the complexity of crises has become a convenient way of deflecting responsibility for the negative consequences of humanitarian action from the international aid regime to the context in which it operates." $" 50$

\section{Human Rights, Business and Development}

Under human rights, Do No Harm's status as a legal principle - even with the 'in passing' uses - is easier to discern. Mostly, Do No Harm is used interchangeably with the (legal) obligation to 'respect' human rights, usually in connection to social and economic rights, although there are more recent examples of its use in relation to civil and political rights. ${ }^{51} \mathrm{In}$ those cases, it acts as a legal shorthand, mostly playing the role of "elaborative" principle. ${ }^{52}$ In other instances, Do No Harm appears as part of efforts to generate new norms, or to extend existing obligations, to deal with new areas and actors. This was the case, historically, with Do No Harm's first uses, which appeared as part of efforts to clarify the extra-territorial obligations of states, in respect to the rights to food and health. Of note, the former Special Rapporteurs on the rights to food and health (respectively, John Ziegler and Paul Hunt) used Do No Harm language to assert that various international policies, such as trade rules and development conditionalities, should avoid harming economically poor populations in de-

49 The apparent lack of mechanisms for accountability for harms has recently been captured by the attempts to seek redress from the UN for cholera outbreaks following the 2010 earthquake in Haiti that were attributed to UN Peacekeeping forces that intervened in the country. The UN has asserted immunities in the face of potential legal action. For more detail see Yale Law School, note 43.

50 Terry, note 33, p. 15 .

51 Do No Harm did not appear in the original articulations of the economic and social rights respect, protect and fulfilment framework. It was first introduced by Asbjørn Eide, when acting as Special Rapporteur on the Right to Food (see e.g. Asbjørn Eide, The right to adequate food and to be free from hunger: Updated study on the right to food, UN Doc. E/CN.4/Sub.2/1999/12 (28 June 1999), who was drawing on earlier writings of Henry Shue (see e.g. Henry Shue, Basic Rights: Subsistence, Affluence and U.S. Foreign Policy, $2^{\text {nd }}$ ed, Princeton 1996, p. 52).

52 The notion of "elaborative soft law" is borrowed from Chinkin, note 38, p. 30, which she describes as "principles that provide guidance in the interpretation, elaboration, or application of hard law." For an example in relation to civil and political rights, see e.g. $U N O H C H R$, Preventing intimidation and reprisals against human rights defenders (25 October 2011), http://www.ohchr.org (last accessed on 17 March 2014). Other examples include human trafficking and child rights. 
veloping countries. ${ }^{53}$ Given the relatively limited territorial scope traditionally accorded to international human rights treaty obligations, for instance, by the UN Human Rights Committees, Do No Harm is arguably employed in those instances as a soft law, gap-filling norm, in other words, as both a norm of 'aspiration' and a 'combination' norm, inasmuch as it seeks to draw on elements of existing hard law obligations (although the Special Rapporteurs would likely have claimed they were simply clarifying the proper scope of those obligations) ${ }^{54}$ Similar uses of Do No Harm are also seen in more recent efforts to apply human rights to the activities of businesses and transnational corporations and official development assistance (ODA), which this section will examine in more detail.

\section{Human Rights \& Business}

In the case of human rights and business, Do No Harm is clearly used as part of efforts to generate new norms, notably by John Ruggie in his earlier work as Special Representative of the Secretary-General on the issue of human rights and transnational corporations and other business enterprises. In articulating the "Protect, Respect and Remedy" framework, which eventually fed into the UN Guiding Principles on Business and Human Rights (Guiding Principles), ${ }^{55}$ Ruggie on a number of occasions explicitly uses Do No Harm language to describe the responsibility of businesses to respect human rights. ${ }^{56}$ Do No Harm's meaning in this context is quite extensive, since it derives from the rules and guidance provided on the responsibility of businesses to respect rights. The Guiding Principles outline three main requirements for businesses to discharge their responsibility to avoid harm - "a statement of policy commitment, a human rights due diligence process and processes to enable remedia-

53 Jean Ziegler, The right to food - Report of the Special Rapporteur on the right to food, UN Doc. E/ CN.4/2005/47 (24 January 2005), para. 49 and Paul Hunt and Gunilla Backman, Health systems and the right to the highest attainable standard of health, Health and Human Rights 10 (2008); Paul Hunt, Report of the Special Rapporteur on the right of everyone to the enjoyment of the highest attainable standard of physical and mental health, (Addendum), UN Doc. A/HRC/7/11/Add.2 (5 March 2008).

54 Notions of norms of aspiration and combination norms are borrowed from Reidel, note 22, pp. 67-9. Since Ziegler's initial uses, Do No Harm has also appeared in relation to areas such as the right to water (in respect to corporations) and the right to adequate housing. On the right to housing, see Raquel Rolnik, Report of the Special Rapporteur on adequate housing as a component of the right to an adequate standard of living, UN Doc. A/66/270 (5 August 2011), p. 21 discussing disasters.

55 UN OHCHR, Guiding Principles on Business and Human Rights - Implementing the United Nations "Protect, Respect and Remedy" Framework, HR/PUB/11/04, Geneva and New York, 2011.

56 John Ruggie, Protect, Respect and Remedy: A Framework for Business and Human Rights - Report of the Special Representative to the Secretary-General on Business and Human Rights, UN Doc. A/ HRC/8/5 (2008), para. 34. Also, John Ruggie, Statement by Prof. John Ruggie, Special Representative of the Secretary-General on Human Rights and Transnational Corporations and Other Business Enterprises, UNGA $63^{\text {rd }}$ Sess., $3^{\text {rd }}$ Comm. $(27$ October 2008), www.hks.harvard.edu (last accessed on 17 March 2014). 
tion" - which each include additional detailed guidance. ${ }^{57}$ Interestingly Do No Harm appears in Ruggie's background reports but not explicitly in the Guiding Principles which, though non-binding, have clear "textual characteristics of binding international treaties" and can fairly uncontroversially be described as a 'soft law' instrument. ${ }^{58}$ That said, Do No Harm language appears to have quickly gained currency as a principle in the human rights and business context. This is evidenced, for instance, by efforts of non-governmental organizations to provide guidance to companies on the various Do No Harm requirements, such as due diligence. ${ }^{59}$

Do No Harm in this context can thus be characterized as a soft law norm (of aspiration), though one that tracks closely the language of familiar hard law norms. The main feature to highlight about Do No Harm, in this connection, is that it is both a procedural standard and a "standard of result." 60 The due diligence requirements and language of risk mitigation are largely procedural, and speak to ensuring that certain steps are taken and processes in place when conducting activities, for instance, to communicate with affected stakeholders. ${ }^{61}$ As some commentators have noted, those requirements are familiar "in standard business practices with respect to managing other sources of risk... such as in the field of anti-corruption or in social and environmental impact," and have affinities to notions of risk mitigation and a private law standard of care. ${ }^{62}$ At the same time, the responsibility to respect human rights carries additional requirements, notably, to provide a remedy where businesses impinge on (harm) the rights of individuals. ${ }^{63}$ This is where the "standard of result" arises: harms must be made whole by way of a remedy. Taken together, Do No Harm's procedural risk mitigation and due diligence requirements are only one part of a larger framework of accountability. They are concomitant with crucial, additional responsibilities to remedy harms where they occur.

\section{Human Rights \& Development Effectiveness}

The links between mitigating risks and providing remedies, by contrast, are not as pronounced when Do No Harm is employed in the official development assistance (ODA) context, espe-

57 UN OHCHR, The Corporate Responsibility to Respect Rights - An Interpretive Guide, Geneva 2012, para. 13.

58 Goldmann, note 22, p. 335 .

59 Global Witness, A Guide for Companies - Do No Harm: Excluding Conflict Minerals from the Supply Chain, London, July 2011; and Right2Respect, Business and Human Rights Advisers, "Respecting" Human Rights: What Does it Mean to "Do No Harm"?" (April 2011), www.right2respect.com (last accessed on 17 March 2014).

60 Right2Respect, Business and Human Rights Advisers, note 59.

61 Ruggie, note 10, para. 21.

62 Mark B. Taylor, Luc Zandvliet and Mitra Forouhar. Due Diligence for Human Rights: A Risk-Based Approach, Corporate Social Responsibility Initiative Working Paper No. 53, John F. Kennedy School of Government, Harvard University, Cambridge, MA 2009, p. 6.

63 The content of the rights extends to the international bill of human rights and other prominent international human rights conventions like the ILO core conventions. Ruggie, note 56, para. 58. 
cially when looking at accountability of donors to human rights. Notions of Do No Harm are familiar to ODA practice, to be clear, appearing in connection, for instance, with the mandatory rules under social and environmental safeguards that multilateral development banks (MDBs) apply to their project financing. ${ }^{64}$ Do No Harm "is not contained as a general principle in a mandatory ... policy" in those instances but, rather, plays the role of an "elaborative principle,' as seen above with human rights obligations. ${ }^{65}$ In this case, Do No Harm captures the basic risk mitigation and due diligence logic underlying detailed sets of mandatory safeguard rules, which in many ways follows environmental law notions of avoiding harm discussed below. The distinctive character of the mandatory safeguard rules is that they are embedded within a larger procedural framework, under which individuals can essentially seek redress by way of independent mechanisms, such as an Inspection Panel or Compliance Officer. Those bodies can go as far as recommending compensation, where there is failure to comply with the mandatory risk mitigation and due diligence rules, which begins to resemble a remedial mechanism to ensure accountability of donor activities for harms. ${ }^{66}$

The independent complaint mechanisms are notable exceptions, however, because avenues for ensuring donor accountability are, otherwise, decidedly soft. Witness, for instance, a major international development policy document such as the Paris Declaration on Aid Effectiveness (Paris Declaration), which only goes as far as affirming the principle of 'mutual accountability.' In respect to donors, this notion of accountability is restricted to a political one, namely, of governments providing "timely, transparent and comprehensive information on aid flows... to their legislatures and citizens," with no mention of donors being legally accountable to affected individuals. ${ }^{67}$ This approach to accountability arguably surfaces in efforts to link human rights to ODA under the larger aid effectiveness agenda, where Do No

64 IEG (World Bank), Safeguards and Sustainability Policies in a Changing World An Independent Evaluation of World Bank Group Experience, Washington, DC, 2010, pp. 7-8. Note that Do No Harm also appears as part of guidance ensuring country ownership in assistance emphasizing sensitivity to context; David Booth, Aid effectiveness: bringing country ownership (and politics) back in, Overseas Development Institute Working Paper 336 (2011), p. 8. Also, the UK government has evoked Do No Harm to underscore the importance of ensuring policy coherence for development. House of Commons, UK, The Commission for Africa and Policy Coherence for Development: First do no harm, First report of the 2004-5 session, HC 123 (December 2004), p. 15.

65 In this connection, see von Bernstorff and Dann, note 20, p. 13 on Do No Harm's safeguards' connections; IEG (World Bank), Safeguards and Sustainability Policies in a Changing World: An Independent Evaluation of World Bank Group Experience, Washington, DC, 2010, pp. 7-8.

66 Formally speaking, the Inspection Panel or Compliance Officer, depending on the institution, would review the application of the safeguards policies by the MDB, and make recommendations to its Board, who would then decide on how to implement those recommendations in discussion with the recipient country in question.

67 OECD, The Paris Declaration Aid Effectiveness and Development Effectiveness (2005), para. 49. This understanding was carried forward in the OECD's Accra Agenda for Action (2008); and the OECD's Busan Partnership for Effective Development Co-Operation (2011), para. 11(d). See also Marta Foresti, David Booth, and Tammie O'Neil, Aid effectiveness and human rights - strengthening the implementation of the Paris Declaration (October 2006), www.odi.org.uk (last accessed on 17 March 2014). 
Harm is again front and centre. Two examples are worth considering in this connection. The first is a 2007 Action-Oriented Policy Paper on Human Rights and Development ("Policy Paper"), developed by the OECD's Development Action Committee's (DAC). ${ }^{68}$ The Policy Paper contains 10 Principles, which are described as "basic orientations," including one labeled as "Do No Harm" (Principle 8). That Principle calls on donors to "respect human rights principles in their policies and programming" and emphasizes the need to develop strategies to mitigate potential harm. ${ }^{69}$ What practically Do No Harm means here, in terms of respecting human rights principles, however, is left unclear.

On the one hand, it could imply the more focused human rights "respect" meaning discussed above, which imposes a requirement to provide a remedy for harms. Any such a requirement, on the other hand, would arguably be too significant to be left implicit. Without saying more, Principle 8 thus might only go as far as affirming existing safeguard approaches seen above, which would be consistent with its language of mitigating negative impacts. That said, the Policy Paper falls entirely silent on the issue of redress for failure to respect human rights principles. For instance, there is no mention of "codes of conduct for agency staff and project implementers or complaint or redress mechanisms accessible to beneficiaries so that they can hold agencies to account," which were recommended in a background report that fed into the Policy Paper.$^{70}$ Even then, following a safeguard approach would present an additional set of challenges, as will be argued in the next section, related to potential clashes between the respective logics of the environmental and human rights regimes. From an international law lens, the Policy Paper's use of Do No Harm might generally seem inconsequential. Any commitments in the Paper are clearly restricted to a political or policy level, and at most contain possible elements of a 'combination' norm by making reference to human rights principles, and the obligations of States under international human rights treaties as the source of human rights. Where the Policy Paper's use of Do No Harm gains significance, however, is that its prescription for donors to "respect human rights principles," which is

68 OECD, Development Assistance Committee, Action-Oriented Policy Paper on Human Rights and Development (2007), www.oecd.org/dac/governance/humanrights (last accessed on 17 March 2014). The paper speaks of human rights not only as a tool for more effective aid but also in a "Setting the Stage" section in terms of "mobilising social change; transforming state-society relations; removing the barriers faced by the poor in accessing services; and providing the basis for the integrity of information services and justice systems needed for the emergence of dynamic market-based economies".

69 OECD, Development Assistance Committee, note 68. See also Laure-Hélène Piron, Rights-based Approaches and Bilateral Aid Agencies: More Than a Metaphor?, IDS Bulletin 36.1 (2005), p. 21, addressing the negative impacts of aid (the "do no harm principle"), which requires human rights impact assessments and monitoring systems.

70 Laure-Hélène Piron with Tammie O’Neil, Integrating Human Rights into Development. A Synthesis of Donor Approaches and Experiences, London 2005, p. 22. 
arguably severed from the core human rights obligation to provide a remedy for violations of rights, appears not to be an isolated case. ${ }^{71}$

To illustrate, consider the Canadian Official Development Assistance Accountability Act ("ODAAA"), which seeks to ensure, among other goals, that all Canadian ODA "is provided manner that is consistent with the Paris Declaration ... and that promotes international human rights standards." ${ }^{, 72}$ The $O D A A A$ imposes two basic requirements to achieve those goals. First, ODA shall only be provided if, among other things, it is consistent with Canada's international human rights obligations. ${ }^{73}$ Secondly, competent ministries must report to Parliament on a yearly basis, among other matters, on activities falling under the Act, which essentially gives effect to the Paris Declaration commitment to mutual accountability, qua transparent information flows. ${ }^{74}$ The first requirement related to Canada's international human rights obligations has been dubbed a Do No Harm approach, both by the Canadian government in its reports to Parliament under the Act and by civil society organizations when critiquing the government's approach. ${ }^{75}$ Those critiques center on the government's failure to provide evidence to support claims that all Canadian ODA activities are consistent human rights, which is seen as symptomatic of an overly minimalist approach by government to avoid harm. ${ }^{76}$ Indeed, from the documents reviewed, it is difficult to discern what if any impacts the ODAAA has had on Canadian ODA or, for that matter, in helping better detect and avoid harms to human rights

71 In this connection, see e.g. Asbjørn Eide, The Health of the World`s Poor-a Human Rights Challenge, Norwegian Directorate of Health Report IS-0337, Oslo 2011, p. 98, discussing mutual accountability in relation to Principle 8 of the Policy Paper: "But what about the accountability of the donor governments - to which extent are they ready to recognize an obligation to contribute towards global health? Are they ready for reciprocal accountability or even for some form of independent review and remedy mechanism which can address both donors and recipient countries?".

72 Official Development Assistance Accountability Act, note 6, s. 2(1).

73 Ibid., s. 4(1), and also contributes to poverty, takes the perspectives of the poor into account.

74 Ibid., s. 5.

75 For government use of Do No Harm, see e.g. Internal Audit and Evaluation Department of Finance Canada, Evaluation of Canada's Payments to the International Development Association (IDA) Final Report (4 January 2012), www.fin.ga.ca (last accessed on 17 March 2014).

76 Brian Tomlinson, Canada's ODA Accountability Act: Legislating for Canadian ODA to Focus on International Human Rights Standards, in: Reality of Aid, Aid and Development Effectiveness: Towards Human Rights, Social Justice and Democracy - Reality of Aid Report 2010, Quezon City, Philippines, 2010, p. 67. Consultation with civil society and government agencies under the ODAAA is required at least once every two years under s. 4(2). See also debate of the government's report in Senate of Canada, Report on Canadian Official Development Assistance in International Cooperation - Report on Canadian Official Development Assistance, Debates of the Senate (Canada), $3^{\text {rd }}$ Session, 40 ${ }^{\text {th }}$ Parliament, Vol. 147 (27 October 2010), p. 1235. See generally Canadian Council for International Cooperation, A Time to Act - Implementing the ODA Accountability Act: A Canadian CSO Agenda for Aid Reform, Ottawa 2010. 
on the ground. ${ }^{77}$ Finally, as with the Policy Paper, the ODAAA requirement that Canadian ODA be consistent with human rights fails to specify a further mechanism for individuals to seek legal redress, where Canadian ODA does harm their human rights.

\section{General Conclusions}

Returning to this paper's backdrop, when used as part of efforts to develop or extend norms, Do No Harm plays the role of a norm of aspiration that flags emerging areas, where there are gaps in existing hard law norms. The contrast in approaches between Ruggie's Guiding Principles and efforts in the ODA context demonstrate possible risks associated with Do No Harm's open-ended language. Although both claim to ground Do No Harm in established international human rights obligations, only the human rights and business meaning remains truly faithful to those obligations, by explicitly linking the 'responsibility to respect' to the requirement to provide a remedy. ${ }^{78}$ Query however whether there is greater appetite for increasing accountability of businesses to human rights precisely because any new obligations are voluntary, constraining only non-state actors and not states as in the ODA context. This contrast in meanings points to a potentially troubling conclusion, namely, that the human rights and ODA uses of Do No Harm could yet undermine efforts to promote a richer sense of accountability and to give better expression to international human rights obligations precisely because they delink the commitment to respect human rights from the obligation to provide a remedy. Do No Harm, when embedded in a framework of development effectiveness, thus arguably masks a crucial lack of political will to provide more meaningful scrutiny of, and accountability for, the negative human rights impacts of ODA.

A lack of political will is arguably also apparent from the failure to address how clashes or potential trade-offs between rights should be resolved. This is a crucial parallel to the humanitarian assistance experiences. As seen in that context, trade-offs arise immediately in discussions of Do No Harm, especially in situations where avoiding harms means choosing between harms to different groups or harms arising in the short-, medium or long-term. In the case of human rights and development, a classic example of analogous trade-offs are seen in situations of widespread human rights violations in a recipient country, where 'doing no harm'

77 This conclusion would also apply to the Principle 8 of the OECD Policy Paper. A notable exception is the Danish government's recent development strategy which is explicitly billed as taking a human rights-based approach to development and states that "Accountability also applies to us. If people in our priority countries experience adverse consequences of our development cooperation, they must be able to complain directly to Danish embassies." The Danish Government, The Right to a Better Life: Strategy for Denmark's Development Cooperation, Copenhagen 2012, p. 11. The strategy however nowhere refers to 'Do No Harm'.

78 See also Committee on Economic Social and Cultural Rights, General Comment 3, The Nature of States Parties' Obligations, U.N. Doc. E/1991/23, annex III (1990), para. 86 in respect to economic and social rights; and Human Rights Committee, General Comment 31, Nature of the General Legal Obligation on States Parties to the Covenant, U.N. Doc. CCPR/C/21/Rev. 1/Add.13 (2004), paras. $8,15-7$. 
might force donors to choose between suspending aid to avoid contributing to rights' violations in any way, or continuing to provide assistance to avoid imposing any "double punishment" on affected populations (e.g. by cutting off vital support for essential services). ${ }^{79}$ The choice between alternatives in many cases would likely not be so stark. The failure to recognize such trade-offs between rights, let alone provide guidance to resolve them, nonetheless raises questions about the political will to give effect to a Do No Harm principle.

The human rights uses of Do No Harm are relatively recent and their longer-term potential, especially in contributing to "emergent hard law," thus depends on whether one takes a glass half-full or half-empty view. Since Do No Harm appears largely in policy documents such as the Policy Paper or in connection with soft law documents such as Guiding Principles on Human Rights and Business, Do No Harm's role in helping develop emergent and binding obligations ultimately depends on how much traction those documents receive; for instance, whether they spur additional policy and reform efforts, and are translated into binding legal obligations. ${ }^{80}$ The Canadian $O D A A A$ offers a possible cautionary tale of how, even when translated into binding domestic legislation, an impact assessment or due diligence obligation, in practice, might be thin at best. This suggests again that the open-ended nature of Do No Harm, as a principle, makes it susceptible to politically expedient uses, which do not necessarily translate into concrete rules or action. And since Do No Harm in this context is linked to existing obligations, query whether such uses could serve to water down existing, binding commitments to respect human rights, such as the basic obligation to provide an effective remedy in cases of violation. This could yet be a case of soft law providing "a smoke screen behind which governments can shelter when demands for compliance are made," ${ }^{81}$ which would be the glass half-empty view.

The glass half-full view, by contrast, sees the open-ended nature of Do No Harm as an opportunity. Being susceptible to political contestation is precisely what makes Do No Harm amenable to efforts to extend the application of human rights more forcefully into relatively unchartered terrain (i.e. horizontally with business, and extra-territorially with ODA). In this sense, once introduced into policy debates, Do No Harm helps open the door to creating or extending obligations - a case of soft law serving an "emancipatory purpose." 82 To illustrate, McInerney-Lankford and Darrow argue that Do No Harm stands as a core obligation to perform due diligence under both human rights and multilateral environmental agreements - in the case of human rights, emanating from existing obligations of states and, in the case of environmental law, as either a general principle of international law or norm of customary international law. The authors further point to past U.N. practice to assert an international

79 Roberto Dañino, The Legal Aspects of the World Bank's Work on Human Rights, Development Outreach 8(2) (2006), p. 32. See also OECD, Development Assistance Committee (Fragile States Principles), note 39, para. 2.

80 Prosper Weil, Towards Relative Normativity in International Law?, AJIL 77 (1983) 413, p. 417.

81 Chinkin, note 38, p. 42.

82 Goldmann, note 22, p. 356. 
responsibility (at least of the $\mathrm{UN}$ ) to provide damages for harms caused by its operations. ${ }^{83}$ This standpoint stands in direct contrast to, for instance, $O D A A A$ practice or the language of the Policy Paper. Will those authors' attempts to ground Do No Harm in hard law sources ultimately prevail? Optimistically, the unassailable moral weight of Do No Harm could yet make it a 'sticky' norm. Who after all would claim to back away from a principle, once stated, to doing no harm? Moreover, once introduced, it might create an impetus over time to resolve the very questions and tensions it helps to lay bare. This suggests that Do No Harm could yet offer a useful principle for advancing contested normative projects. The challenge however remains in the details.

\section{International Environmental Law \& General Conclusions about Do No Harm}

Do No Harm has had a somewhat different history under international environmental law than in the humanitarian assistance and human rights contexts. The principle originated in the Trail Smelter case, as a prohibition on trans-boundary pollution, and was later reaffirmed in the ICJ's Nuclear Weapons advisory judgment and major international environmental instruments such as the Stockholm and the Rio Declarations. ${ }^{84}$ As such, the principle does not appear to have been inspired by the Hipprocratic Oath, and terminology such as "Prevention of Harm" or "No Harm" is commonly found, rather, than the specific "Do No Harm" formulation. Moreover, those terms do not actually appear in the sources such as Trail Smelter or the Stockholm Declaration, but are used more as an elaborative term to the capture the duty to

83 And presumably of states and other international organizations for their operations. McInerneyLankford, Darrow, and Rajaman, note 17, pp. 45-7 and accompanying citations. Interestingly, to the extent that the authors rely on existing sources of international law to argue for a human rights obligation to perform due diligence or to Do No Harm, those sources primarily involve state responsibility at a state-to-state or international organization-to-state level, which also generally mirrors obligations under multilateral environmental agreements. This feature of their analysis is notable if only because human rights obligations generally situate the obligation and remedy framework as between states and affected individuals and not strictly at the state-to-state or IO-to-state level, which was in fact the case in the Belgian Nationals and UN damages example the authors rely on. This points to some of the difficulties in crystalizing the extra-territorial obligations and remedies of international human rights. That said, this point could be over-stated inasmuch as various international obligations of states, at a state-to-state level, have been recognized as creating rights for individuals, not previously envisaged, as seen in the Case Concerning Avena and Other Mexican Nationals (Mex. v. U.S.), 2004 I.C.J. 12 and Case Concerning LaGrand (Germany v. United States of America), 1999 I.C.J. Rep. 9, both involving the Vienna Convention on Consular Relations, 596 U.N.T.S. 261, entered into force 19 March 1967. See also Siobhan McInerney-Lankford, International Financial Institutions and Human Rights: Select Perspectives on Legal Obligations, in Daniel Bradlow and David Hunter (eds.), International Financial Institutions and International Law, London 2010, p. 70-2 for a discussion of Do No Harm's value as an explicit normative baseline against which to assess development assistance.

84 Stockholm Declaration on the Human Environment of the United Nations Conference on the Human Environment, June 16, 1972, 11 I.L.M. 1416 (1972); Rio Declaration on Environment and Development, U.N. Doc. A/CONF.151/26 (Vol. 1) (12 August 1992). 
prevent trans-boundary environmental harms. ${ }^{85}$ Given some of these differences, the international environmental law uses of Do No Harm would not have been considered here, were it not for the various attempts to draw links between them and the international human rights uses.

The duty not to cause harm under international environmental law is grounded in the sovereign equality of states and state responsibility under international law. States have the right to exploit resources within their jurisdiction provided they do not hinder the enjoyment of other States of their resources. Over time, the duty to prevent transboundary environmental harm has been increasingly asserted as a norm of customary international law - though not without some controversy. ${ }^{86}$ Without entering into those debates, the duty to prevent transboundary harm has been extended to many areas and now appears in a large "number and diversity of legal instruments." The resulting duty has been described as "complex" and "can perhaps better be considered an overarching aim that gives rise to a multitude of legal mechanisms, including prior assessment of environmental harm and procedures to license or authorize hazardous activities, including setting the conditions for operation and the consequences of violations." ${ }^{" 87}$ Additional requirements cited under the duty to prevent harms include monitoring, notification and exchange of information. A core duty of note is the obligation to perform due diligence. Striking about those notions of due diligence - and of prior analysis of the impacts of activities - are their affinities to human rights and humanitarian assistance uses of Do No Harm. More on this below.

Debates remain as to how far the prohibition on transboundary harm extends, for instance, whether it creates an obligation to perform environmental impact assessments, or applies to issues such as climate change. ${ }^{88}$ Healthy debate also persists over how to assess the scope of harm. In this connection, a series of potential trade-offs arise that would apply equally to human rights and humanitarian assistance uses of Do No Harm: should harms arising from activities be assessed solely in terms of single activities or interventions, or the cumulative effect of different interventions? Should their impacts be measured in the short-term or the long-term? Finally, does preventing harm ever extend beyond avoiding certain actions or negative impacts, and entail taking positive action, or promoting certain goals or outcomes? ${ }^{99}$ Based on the analysis above, I would argue that Do No Harm is too open-ended to resolve such trade-offs per se. The experiences in international environmental law are instructive however because they demonstrate how a sustained commitment to a principle to do no harm, as an "overarching aim," could help to spur additional, more detailed rules. The

85 Stockholm Declaration, note 84, Principle 21.

86 See Philippe Sands and Jacqueline Peel, Principles of International Environmental Law, $3^{\text {rd }}$ ed., Cambridge, UK 2012, pp. 195-200 for a helpful overview.

87 Donald Anton and Dinah Shelton, Environmental Protection and Human Rights, Cambridge, UK 2011, p.81.

88 See e.g. McInerney-Lankford, Darrow, and Rajaman, note 17, pp. 45-6.

89 E.g. in the human rights context, this might entail promoting better access to justice or stronger legal systems, so that affected individuals have the means to seek a remedy for harms. 
Guiding Principles on Human Rights and Business, the OECD's work on peace-building, point in the direction. At the same time, the risks seen above, concerning Do No Harm's at once open-ended but morally unassailable language, should still be heeded. Even as an overarching aim, the principle risks lending a false imprimatur that then serves to mask potentially weak political will to assume full responsibility for harms and, importantly, to resolve some of the deeper trade-offs inherent in avoiding harm.

An additional feature common across areas is Do No Harm's definition as a principle to analyse the contexts in which activities are undertaken, in order to mitigate potential harms. The significance of such an emerging principle should not be understated. Do No Harm represents an acknowledgement by international actors that their activities can have unintended harms, and that actors have a responsibility of one kind or another to mitigate those impacts. This recognition, while perhaps obvious in retrospect, appears nevertheless to mark an important departure from earlier understandings of the nature of international assistance, inasmuch as it was previously undertaken without much serious prior analysis or regulation of note. The recognition of a need for greater rules of responsibility implicitly represents the view that the inherent worth of an activity is not in-of-itself sufficient to prevent harm or to justify harms when they arise. Rather, even the most universally unassailable goals, when pursued in practice, require consideration of how they should be tailored to a given context. In this light, Do No Harm's value appears, as much as anything, to be a principle to take context seriously, which serves at the same time to flag areas where greater guidance is needed.

At the same time, I would argue that there is an important risk associated with this shared principle, which might explain the apparent lack of political will of international actors to assume greater responsibility for harms, and resolve the deeper tensions that Do No Harm helps lay bare. The risk is that Do No Harm's increased use is symptomatic of a growing trend by international actors to taking an 'overly managerial' approach to interventions (be they human rights, humanitarian aid, development programming, etc.). Under this characterization, international actors are seen as reducing questions of compliance and accountability to largely technocratic functions, more traditionally seen in accounting and financial management; for instance, through use of checklists and indicators, as part of a larger preoccupation with monitoring the results of interventions. A main critique directed at the emphasis on monitoring and indicators is that it risks depoliticizing "choices that would otherwise be openly contested in the public sphere." This raises the greater risk, in turn, of "collapsing the very space for democratic participation and accountability that is required by human rights law." 90

Do No Harm arguably plays a similarly 'technocratising' role in the instances where its meaning is restricted to a due diligence function and notions of political accountability

90 Margaret L. Satterthwaite and AnnJanette Rosga, The Trust in Indicators: Measuring Human Rights, IILJ Working Paper 2008/12 (Global Administrative Law Series); Sally Engle Merry, Measuring the World: Indicators, Human Rights, and Global Governance, Current Anthropology 5 (2011); Galit Sarfaty, Regulating Through Numbers: A Case Study of Corporate Sustainability Reporting, Va. J. Int'1 L. 53 (2013), p. 621; Lauren B. Edelman et al., Diversity Rhetoric and the Managerialization of Law, Am. J. Soc. 106 (2001), 1589. 
premised on greater information flow. The emphasis there appears largely to come at the expense of a richer form of accountability, such as remedies, which aim to restore the dignity, equality and self-determination of affected individuals. ${ }^{91}$ Rather, Do No Harm is arguably defined and applied in a top-down manner, leaving negatively affected populations to play a passive role. Stated differently, Do No Harm's various uses appear somewhat inwardly centred on, and driven by, those providing the assistance (i.e. by and for the international actors). This is a notion of accountability that seeks to contain the responsibility of donors: it collapses the space for meaningful accountability, by failing to recognize the full protections needed to ensure that populations, when harmed by assistance, are able to seek redress. Lost in the process, paradoxically, would be the full agency and voice, as rights-holders, of those receiving assistance. ${ }^{92}$ At the extreme, delinking the monitoring and redress functions could result in a notion of Do No Harm that fails adequately to give expression to the political or transformational nature of processes such as conflict or development. ${ }^{93}$ This is another way of saying that it would fail to meaningfully embed context in activities so as to avoid, be more responsive to, and responsible for harms. In that case, practices associated with Do No Harm would fail to follow-through on the very insights that originally drove its introduction into the international lexicon.

\section{F. Uses of Do No Harm in Converging Spaces of International Operation}

Do No Harm's various uses, I have argued, leave open important questions about how to resolve trade-offs between potential harms. The trade-offs considered to this point are largely those arising within each area, that is, when human rights, humanitarian assistance, environmental law consider, on their own respective terms, how to define harm and resolve potential trade-offs. This final section will examine an additional set of potential trade-offs, which arise in situations where Do No Harm's different uses collide in two or more areas. These potential clashes are relevant to consider because, as already noted, various documents and authors have sought to ground uses of Do No Harm in one area of activity, by making links to parallel uses in other areas. In the process, Do No Harm is presented as a potentially unifying principle across regimes, but without necessarily going the step further and identifying where possible points of convergence or incongruence lie. A further reason for considering potential clashes is that the areas of activity where Do No Harm is invoked are themselves increasingly over-

91 Shelton, note 19, pp. 11-2.

92 See generally, UN OHCHR, Frequently Asked Questions on a Human Rights-Based Approach to Development Cooperation, New York and Geneva, 2006.

93 For a wider discussion of how managerial approaches to international law, see René Urueña, No Citizens Here: Global Subjects and Participation in International Law, Leiden 2012, pp. 74-76, who argues in connection to international economic law that the managerial approach guts international law of its normative pull. See also in this connection, Martti Koskenniemi, The Fate of Public International Law: Between Technique and Politics, Modern Law Review 70, p. 1. 
lapping, whether in practice or as part of deliberate efforts to increase normative coherence between them. Do No Harm's various uses, in other words, exist increasingly less in isolation.

A notable example arises in comments by the UN High Commissioner on Human Rights, who stated before the UN Secretary-General's High Level Panel on UN System-wide Coherence in the Areas of Development, Humanitarian Assistance and the Environment, that "[i]n substance, our work must be grounded in the moral and legal obligation to 'do no harm' in connection with the human rights obligations that UN member States have voluntarily undertaken under international human rights treaties." 94 In making those remarks, the High Commissioner was asserting that human rights - and presumably the obligation to respect should guide attempts to create coherence between development, humanitarian assistance and the environment. Similarly, the Inter-Agency Standing Committee (IASC) in a recent set of Operational Guidelines on the Protection of Persons in Situations of Natural Disasters states that "Humanitarian and development actors are committed to respect human rights guarantees, in particular civil and political rights, a commitment embodied in the principle of "do no harm." 95 These statements on the surface seem relatively straightforward. But, on further inspection, they appear to gloss over an important set of tensions that potentially arise between Do No Harm's different meanings. For one thing, as seen above, Do No Harm is accorded a full range of normative weights, depending on whether a human rights, humanitarian assistance or environmental law notion is applied; viz. as an ethical principle, a principle to guide policy or operational best practice (containing varying degrees of prescription or open-ended guidance), a soft law norm, a hard law obligation, and as a norm containing elements of customary international law (e.g. in relation to due diligence to mitigate environmental harms). For another thing, different consequences are prescribed for when harms arise, from an explicit obligation to provide a remedy and mechanisms for seeking one; best practice or policy guidance to change programming ex ante or mid-course; to no clear indication at all of what the consequences should be. Which normative weight then is being asserted in the statements to Do No Harm above? What consequences should flow from harm? These questions are far from academic and point to additional clashes that Do No Harm's uses risk glossing over, as illustrated by the following scenarios.

94 UN OHCHR, Written submissions of the High Commissioner for Human Rights to the UN SecretaryGeneral's High-Level Panel on UN System-Wide Coherence in the Areas of Development, Humanitarian Assistance and the Environment (10 October 2008), www.ohchr.org (last accessed 17 March 2014).

95 IASC, Operational Guidelines on the Protection of Persons in Situations of Natural Disasters, Washington, DC 2011, p. 6. 


\section{Human Rights vs. Environmental Do No Harm}

The first set of potential clashes arise in efforts by both international human rights and environmental law to address climate change. ${ }^{96}$ The application of both human rights and the prohibition on transboundary harm to climate change uses is not fully settled, although there is increasing attention paid to understanding the human rights impacts of climate change, and in ensuring that responses to climate change respect human rights. ${ }^{97}$ A main take-away from those debates is that the substantive goals and obligations under international environmental law and international human rights law are not immediately reconcilable. Notable clashes arise between the human rights of groups and individuals and efforts to protect forests and other large tracks of natural resources. Naomi Roht-Arriaza points to four-real-life cases dam projects in China and Panama, a Norwegian company forest planting project in Uganda under a carbon emissions program and a waste to energy project in Thailand - to illustrate "negative unintended consequences" that the climate change regime, especially clean development mechanisms, can have on human rights. Those include "violations of the rights of farmers or forest peoples, especially indigenous peoples, massive involuntary displacement, or evictions as certain lands become more valuable," as well as indirect impacts on "food, water, and energy security," and likely "violations of civil and political rights and ... increased conflict" due to "resistance to eviction or resource loss." 98

In addition to competing substantive priorities, human rights are said to be more absolutist and centred on minimum thresholds, in contrast to environmental law principles which are more geared towards trade-offs, balancing and political negotiation. In this sense, environmental law "is grounded in the need for mutual action... In contrast, human rights obligations do not depend on reciprocity. States owe obligations not only to one another, but also to individuals; moreover, one state's respect for human rights does not depend on, and may not be conditioned on, compliance by other states." 99 Procedural rights have been cited as a possible area of convergence between the two regimes. However, compliance mechanisms under

96 Naomi Roht-Arriaza, "First Do No Harm": Human Rights and Efforts to Combat Climate Change, Ga. J. Int'l \& Comp. L. 38 (2010), p. 593. See also McInerney-Lankford, Darrow, and Rajaman, note 17, and Timo Koivurova, Review, AJIL 106 (2012), p. 439, discussing Frances Seymour, Forests, climate change and human rights: managing risks and trade-offs, in Stephen Humphreys (ed.), Human Rights and Climate Change, New York 2011..

97 Daniel Bodansky, The Art and Craft of International Environmental Law, Cambridge, MA 2010, p. 516 fn. 5, citing Svitlana Kravchenko and John E. Bonnie, Human Rights and the Environment: Cases, Law, and Policy, Durham, N.C. 2008; and Alan E. Boyle and Michael R. Anderson (eds.), Human Rights Approaches to Environmental Protection, Oxford, UK 1996.

98 Roht-Arriaza, note 96, p. 594. Bodansky, note 97, pp. 594-5. On possible concerns or guidance about clean development mechanisms, REDD programs in particular, see Global Justice Ecology Project, Why REDD is Wrong, http://globaljusticeecology.org (last accessed on 17 March 2014); Center for International Environmental Law, FPIC and UN-REDD: Legal and Practical Considerations (22 January 2010); UN-REDD Programme, Guidelines on Free, Prior and Informed Consent, Draft for Comment (December 2011).

99 Bodansky, note 97, p. 516. 
multilateral environmental agreements are argued to be much weaker than under human rights law, ${ }^{100}$ which is only a relative strength at best, as "relatively few procedural rights are firmly entrenched in international human rights law." ${ }^{101}$ Finally, international environmental law has been argued to be better attuned to accommodating the interests of, and anticipating harms to, future generations than human rights law. ${ }^{102}$

While far from an exhaustive list, these potential points of divergence demonstrate how Do No Harm arguably takes on much different meanings, respectively, under international human rights and international environmental law - whether in terms of the substantive obligations involved, what harms are given priority, who holds what rights, or the remedies and procedural protections available. Further, the above cases involving clean development mechanisms suggest that efforts to avoid harm in one area (i.e. from an environmental standpoint) could in fact lead to harms in other areas (i.e. from a human rights standpoint). This is perhaps a basic point. However, I would argue that those differences in meaning are not sufficiently recognized, for instance, when officials such as the UN High Commissioner for Human Rights cite Do No Harm to convey coherence between the environment, human rights and humanitarian assistance. Documents like the OECD DAC's Policy Paper arguably also fail sufficiently to consider this difference in meanings, when invoking Do No Harm in a way that ambiguously takes it cues from both the human rights and environmental safeguards regimes. In those instances, does Do No Harm mean giving priority to one meaning over the other, or finding a conception of harm and avoiding harm that is common to all areas? The latter option would require a coherent conception of harm which, rather than glossing over differences in meaning, provides a common logic to mediate between the competing priorities and imperatives, where clashes arise.

The High Commissioner's statement presumably favours the human rights conception. By falling silent on this point, however, the statement fails to acknowledge the implicit choice it makes between priorities and, crucially, that "a focus on individual human rights appears to offer little guidance in situations where rights seemingly conflict, as they often do." 103 That choice in turn represents a deeper political choice, at the heart of efforts to achieve coherence between human rights and environmental law. Again, Do No Harm per se is too open-ended to provide a basis for choosing between human rights and environmental notions of harm and 'doing no harm.' The risk then is that by providing a false sense of coherence between regimes, Do No Harm's use detracts attention from the very set of trade-offs that need to be resolved in order to achieve the professed coherence. It begs the questions, in other words. In this way, Do No Harm's rhetorical force might again serve to defer important policy debates. To what extent such concerns are well-founded, to be clear, is a live question, and would warrant

100 Svitlana Kravchenko, Procedural Rights as a Crucial Tool to Combat Climate Change, Ga. J. Int'1 \& Comp. L. 38 (2010), p. 616.

101 McInerney-Lankford, Darrow, and Rajaman, note 17, p. 57.

102 Ibid., p. 46-7.

103 McInerney-Lankford, Darrow, and Rajaman, note 17, p. 57. 
additional investigation, for instance, by trying to develop a better understanding of how policy-makers in the respective fields understand Do No Harm's meaning.

\section{Human Rights vs. Humanitarian Assistance Do No Harm}

Similar trade-offs also arise in a second set of scenarios, involving the increased merging of human rights and humanitarian assistance. These potential trade-offs are witnessed, first, at a policy and conceptual level, as part of efforts to integrate a greater human rights perspective within humanitarian assistance, for instance, around notions of humanitarian protection. ${ }^{104}$ Unsurprisingly, the main trade-offs arising in this case relate to questions of how far to go in respecting human rights principles, at the possible expense of humanitarian principles, and vice versa. ${ }^{105}$ Stated differently, unresolved questions have emerged over the degree to which humanitarian assistance should incorporate "a concern with justice (or injustice)" which is central to human rights, but "is not generally taken to be a defining characteristic of the humanitarian agenda." 106 Indeed, the different levels of concern for justice are seen when contrasting humanitarian assistance's emphasis on prior analysis with the clearer focus on accountability through an obligation to respect embedded in the human rights notion of Do No Harm. This is not to suggest that humanitarian assistance is blind to concerns of justice. After all, it was the questioning of neutrality's continued validity that helped spur Do No Harm's introduction into the humanitarian assistance lexicon. In one sense, this is just a resurfacing of the debates seen above over whether humanitarian assistance should move away from neutrality and condition the provision or suspension of assistance on additional criteria (which in this case might be based, for instance, on the human rights record of the parties to the conflict, or the potential for assistance to fuel additional negative human rights impacts). ${ }^{107}$ Integrating a human rights perspective into humanitarian assistance, however, would push that questioning even further.

Consider, for instance, the IASC Operational Guidelines on the Protection of Persons in Situations of Natural Disasters cited above, which evoke Do Harm in calling on humanitarian and development actors to respect human rights guarantees, especially civil and political

104 Humanitarian protection has many definitions, but is variously described as encompassing the protections under human rights, humanitarian and refugee law. As a general reference see IASC, Growing the Sheltering Tree: Protecting Human Rights through Humanitarian Action (2002). See also Chris Dolan and Lucy Hovil, Humanitarian protection in Uganda: a Trojan Horse?, Overseas Development Institute HPG Background Paper, London 2006, for a succinct discussion of possible ambiguities in the term humanitarian protection.

105 For a general overview of issues and references, see James Darcy, Human Rights and Humanitarian Action: A review of the issues, Overseas Development Institute HPG Background Paper, London 2004, pp. 4-5.

106 Ibid., note 105, pp. at 6-7 and among different humanitarian groups, "objectives vary in the extent to which they invoke the concepts of rights and justice".

107 Ibid., p. 8, noting that "[p] erhaps more than any other part of humanitarian doctrine, it is the principle of neutrality that lies at the heart of debates about rights-based approaches to humanitarianism". 
rights. ${ }^{108}$ To assert in this way that humanitarian assistance should follow human rights obligations arguably presupposes a prior issue, namely, that the applicable legal obligations are well settled. In contexts of humanitarian assistance such as natural disasters, however, which international legal obligations apply remains fluid and ill-defined. ${ }^{109}$ Moreover, in order to fill any gaps in obligations, reference is generally made to established obligations under international human rights law (IHRL) or international humanitarian law (IHL). ${ }^{110}$ Going down that route, however, gives rise to an additional set of potentially unresolved clashes between legal obligations under IHRL and IHL. The relationship between those two regimes has received extensive debate of late, particularly regarding applicable limits to the use of force in contexts of armed conflict. ${ }^{111}$ Doing no harm - qua respecting civil and political rights such as the right to life - might thus have drastically divergent meanings depending on which body of law applies. A somewhat blunt example of this divergence is found in the US government's practice of using drones to carry out targeted killings. That practice has alternatively been characterized as a justified use of military force or as extra-judicial killings, depending on whether, respectively, the prescriptions of IHL or IHRL are deemed to take precedence. ${ }^{112}$ Possible tensions between the two bodies of law also arise starkly in connection with the increasing role humanitarian organizations such as the ICRC are playing in "new," non-traditional spaces of operation, such as "post-conflict settings, urban spaces and what the ICRC describes as "situation other than war." 113 A concrete example of such action - termed humanitarian action in situations other that war ("HASOW") - is the presence of groups such

108 IASC, note 95.

109 And are currently the subject of a number of normative projects. See e.g. Dug Cubie, An Enchanted Tool?: Humanitarian Assistance and the ILC Draft Articles on the Protection of Persons in the Event of Disasters, Irish Yearbook of International Law 4-5 (2009-2010), p. 119; International Law Commission, note 14; and Theodor Meron, On the Inadequate Reach of Humanitarian and Human Rights Law and the Need for a New Instrument, AJIL 77 (1983).

110 See Yale Law School, Transnational Development Clinic, note 43 for an example.

111 For indicative sources in this vast area of discussion see e.g. Hans-Joachim Heintze, On the relationship between human rights law protection and international humanitarian law, International Review of the Red Cross 865 (2004), p. 789; Nehal Bhuta, States of Exception: Regulating Targeted Killing in a 'Global Civil War' in Alston and Macdonald (eds.), note 16; and Theodor Meron, Human Rights in Internal Strife: Their International Protection, Cambridge, UK 1987. Relevant ICJ jurisprudence includes these judgments: Legality of the Threat or Use of Nuclear Weapons, Advisory Opinion, 1996 ICJ Rep. 226 (8 July 1996). Legal Consequences of the Construction of a Wall in the Occupied Palestinian Territory, (2004) ICJ Rep. 136 (9 July 2004). Armed Activities on the Territory of the Congo (Democratic Republic of the Congo v. Uganda), ICJ Rep. 168 (2005) (December 2005).

112 For a relatively recent exchange on these issues see e.g. the views of Harold Koh, The Obama Administration and International Law, Keynote Address at the Annual Meeting of the American Soc'y of Int'1 Law (25 Mar. 2010) and the response to those views in Philip Alston, Study on targeted killings - Report of the Special Rapporteur on extrajudicial, summary or arbitrary executions, UN Doc. A/HRC/14/24/Add.6 (28 May 2010), paras. 18-22..

113 For more detail, see the project on Humanitarian Action in Situations other than War (HASOW), www.hasow.org (last accessed on 17 March 2014). 
as the ICRC and Médecins sans Frontières in Rio de Janeiro, in connection with governmentled operations to clear the favelas of crime and violence associated with long-standing drug gangs. ${ }^{114}$ The government operations are notable because they resemble military interventions but are undertaken in situations that do not clearly or formally qualify as armed conflict. Consequently, the appropriate legal thresholds for using force would arguably be those found under ordinary civilian law (e.g. criminal and constitutional law) and not IHL. ${ }^{115}$

This distinction between applicable laws is important because - as with the use of drones - it goes directly to the question of what would constitute harm or necessary and proportional use of force in such situations; as well as to questions of what are the applicable procedural and substantive protections for individuals affected by the operations. Here is where the potential trade-offs between human rights and traditional humanitarian principles re-emerge starkly. As in situations of traditional conflict, the humanitarian actors might be among the few independent witnesses of abuses committed by parties to the conflict. Similarly, the desire of the humanitarian actors to preserve confidentiality about such abuses, so as not to jeopardize their longer-term ability to intervene and provide assistance, might remain equally strong. Yet, the grounds for humanitarian actors to justify this confidentiality might be increasingly tenuous, under ordinary civilian and human rights law. In other words, even as independent actors, they might actually face a legal duty to divulge information about any alleged human rights abuses or criminal acts witnessed, either of their own initiative or where individuals seek to compel such information (e.g. by way of testimony in court). As some commentators have noted, in contexts of HASOW:

the humanitarian sector is finding that... a business as usual approach may not be appropriate. For one, the application of traditional "conflict" analysis and approaches may be insufficient even if they offer important insights and perspectives. Likewise, humanitarian principles of neutrality, impartiality and independence may have comparatively little purchase. ${ }^{116}$

114 For more detail on the operations in Rio, see $B B C$, Favela Pacified, www.bbc.co.uk/programmes/ p00p1brr (last accessed on 17 March 2014). Additional contexts include: "cities and inner city neighbourhoods of Jamaica's Kingston, Trinidad's Port-of-Spain, Brazil's Rio de Janeiro, Kenya's Nairobi, Nigeria's Lagos, and Yemen's Saa'na ... There, armed groups - ranging from gangs, militia and paramilitaries to narco-trafficking syndicates and terrorist operatives - reportedly feature analogous tendencies as rebels and insurgents including control over defined territorial spaces," $H A$ SOW, note 113 .

115 Robert Muggah and Albert Souza Mulli, Rio Tries Counterinsurgency, Current History 111 (2012), p. 62; Sven Peterke, Regulating "Drugs Wars" and Other Gray Zone Conflicts: Formal and Functional Approaches, HASOW Discussion Paper 2 (2012), www.hasow.org (last accessed 17 March 2014).

116 HASOW, note 113, under "Rationale". For a discussion of applicable legal principles, see Kate Mackintosh, The Principles of Humanitarian Action in International Humanitarian Law, Overseas Development Institute HPG Report 5, London 2000. 
That passage actually points to deeper challenges in applying Do No Harm language to contexts where humanitarian and human rights principles collide. That is, conflict analysis - the core element of humanitarian assistance's conception of Do No Harm - might itself be illsuited to these new contexts, before even turning to additional, unresolved questions as to whether Do No Harm means respect for human rights obligations, and should take precedence over traditional humanitarian assistance principles, or vice versa.

Determining which principles apply in cases of conflict, finally, is fundamentally a question about hierarchies of obligations. Settling on the appropriate hierarchy is as much a political question that cannot be resolved by appealing simply to existing humanitarian or human rights principles. This is where attempts to integrate human rights into humanitarian assistance around conceptions of humanitarian protection have arguably fallen short. As two authors have noted, this "broader view of protection... specifies no hierarchy when it comes to protection activities: all rights are presented as equally important." 117 This, further, is why uses of Do No Harm that suggest apparent coherence between humanitarian assistance and human rights ring hollow. As a principle, Do No Harm can no more easily resolve such questions of hierarchies than the broader human rights and humanitarian assistance regimes that Do No Harm's uses seek to bridge. For this reason, uses of Do No Harm which suggest coherence between areas are premature and should be avoided, as they risk glossing over a deeper need for political clarity on basic questions of which obligations take precedence.

\section{G. Conclusion}

In the final analysis, Do No Harm as a principle for guiding international activities is like a pebble in one's shoe. To evoke notions of avoiding harm is to confront squarely discomforting questions about what harms should be avoided, and what it means to avoid and take responsibility for them. In this way, Do No Harm is a reflexive principle: it helps to restate some of the deepest questions about responsibility for international activities. While Do No Harm appears to be overly open-ended to answer such questions in itself, it nonetheless plays a role in flagging gaps in existing principles and rules of responsibility for harm.

The purpose of assessing Do No Harm from the perspective of international legal accountability, then, was to determine how far the principle's uses have gone in promoting greater responsibility and legal accountability for international conduct. This is not to say that international law should be considered the only legitimate gauge for evaluating attempts to assume responsibility. It is nevertheless a significant measure of how serious international actors are committed to holding themselves to account and assume greater responsibility for harms. To be fair, some of Do No Harm's uses were never intended to create rules of legal accountability, like with humanitarian assistance. Assessing Do No Harm's uses from a legal accountability perspective in those instances might thus risk coming across as a bit of an artificial exercise. Like it or not, however, those earlier uses of Do No Harm language have spread to other areas of 
international activity where international legal accountability is more clearly at play - an arguable sign of the intuitive and persuasive power of Do No Harm language.

Reviewing the various uses demonstrated that the commitment to Do No Harm, as a principle to take responsibility for harms, legal or otherwise, is at best mixed. Strong consensus appears at policy level among international actors to avoid harm, when going into activities, through prior analysis and due diligence, but the commitment is less clear to address harms when they occur. In the case of international human rights, Do No Harm's open-ended language demonstrates how the principle has the power both to help to reinforce efforts to create new obligations (e.g. human rights and business) but also to contribute to a possible watering down of basic obligations, such as providing a remedy for harms. The risk of watering down obligations, in turn, speaks to a major critique leveled at soft law, namely, that it risks creating "indeterminacy" in legal norms. ${ }^{118}$ From the perspective of promoting greater international legal accountability, these risks need to be better heeded. Transplanting principles (that were not necessarily intended to carry legal weight) blindly into the legal sphere should thus be avoided, where it detracts from efforts to promote accountability. In this light, the verdict is still out on human rights and ODA uses of Do No Harm.

Comparing uses across regimes, especially where Do No Harm is transplanted from one to another, also revealed in greater depth how Do No Harm's convenient and self-evident language risks too easily lending a sense of certainty, for instance, as to what it means to avoid harm. Do No Harm lends an illusory sense of coherence to differing notions of harm and responsibility under human rights, humanitarian assistance and environmental law. The overall picture that emerges is quite consistent with the assumption at the outset of this paper, namely, that Do No Harm's use - while helpful in drawing attention to debates and gaps in regulation - might defer meaningful resolution of the tough choices it flags. The tendency to defer such choices can best be described as a lack of political will to confront head-on some of the thorniest questions of how to resolve competing priorities and trade-offs, often in high risk contexts, and where taking responsibility for harms may require, as a first step, choosing to avoid one set of harms, at the expense of causing another. In reviewing Do No Harm's various uses, the ultimate aim was not to resolve those trade-offs. Indeed, some of those issues, such as establishing a hierarchy of priorities, are both perennial and even intractable. The aim rather was much more modest: to draw attention to possible confusions in using Do No Harm. Ultimately, this is a call for greater rigour in use of language - so that terms like Do No Harm are not bandied about indiscriminately; and so that there is a larger recognition of the risks in using language for its convenience or political expedience. After all, true accountability and responsibility for international harms, at a minimum, requires clarity on the basic rules of the game. Do No Harm's uses to date demonstrate how this clarity is still very much a work in progress. The international community has recognized the pebble in its shoe but has failed to take it seriously, preferring for now to keep on walking despite any nagging discomfort that persists. 